TABLE 1. Size of the clips suitable for pulmonary lobectomies

\begin{tabular}{llll}
\hline \multicolumn{1}{c}{ Right side lobectomies } & & Left side lobectomies \\
\hline Upper lobectomy & & & Large clips \\
Truncus anterior & Large clips & Truncus anterior & Medium-large clips \\
$\begin{array}{l}\text { Ascending (posterior/anterior) } \\
\text { Middle lobectomy }\end{array}$ & Medium-large clips & Ascending (posterior/anterior) & \\
$\begin{array}{l}\text { Single artery }(46 \%) \\
\text { Double artery (51\%) }\end{array}$ & Medium-large clips & \\
Lower lobectomy & Medium-large clips & & \\
Apical segmental & & Apical segmental & Medium-large clips \\
Basal trunk & Medium-large clips & Basal trunk & Large clips \\
\hline
\end{tabular}

branch could even result in its avulsion. ${ }^{3}$ Another risk is the failing alignment of the two jaws of the stapler, leading to incorrect positioning of the staples. Primary mechanical malfunction is also possible, ${ }^{3,4}$ and the placement of the stapler by the assistant is not easy during robotically assisted lobectomy. ${ }^{5}$ Last but not least, staplers are expensive (endovascular stapler +1 cartridge $=479$ euros in our hospital) compared with the cost of the Hem-o-lok clips (6-clip blister pack $=46$ euros), and the applicator is free and reusable.

Considering the use of Hem-o-lok clips in pulmonary surgery, we found some favorable conditions. First, the pressure of the pulmonary artery is lower than that of the systemic arteries and the dissection of the lobar branches usually allows the surgeon to achieve a vessel length sufficient to place 3 clips and maintain a 1- to 2-mm cuff of vessel, which is highly recommended. Moreover, it is important to select the appropriate size of the clips to be used; the clips cannot be smaller than the vessel, but should not be larger.

In conclusion, our preliminary experience suggests the utility of Hem-o-lok clips in minimally invasive pulmonary lobectomies. Further larger studies about reliability, safety, and cost-effectiveness are warranted.

\section{References}

1. Ponsky L, Cherullo E, Moinzadeh A, Desai M, Kaouk J, et al. The Hem-o-lok clip is safe for laparoscopic nephrectomy: a multi-institutional review. Urology. 2008; 71:593-6.

2. Szwerc MF, Landreneau RJ, Santos RS, Keenan RJ, Murray GF. Minithoracotomy combined with mechanically stapled bronchial and vascular ligation for anatomical lung resection. Ann Thorac Surg. 2004;77:1904-9; discussion 1909-10.

3. Craig SR, Walker WS. Potential complications of vascular stapling in thoracoscopic pulmonary resection. Ann Thorac Surg. 1995;59:736-7; discussion 737-8.

4. Yim AP, Ho JK. Malfunctioning of vascular staple cutter during thoracoscopic lobectomy. J Thorac Cardiovasc Surg. 1995;109:1252.

5. Melfi FM, Mussi A. Robotically assisted lobectomy: learning curve and complications. Thorac Surg Clin. 2008;18:289-95.

\title{
The option of taking down the Fontan circulation: The Melbourne experience
}

\author{
Ajay J. Iyengar, MBBS, BMedSci, Christian P. Brizard, MD, MS, Igor E. Konstantinov, MD, PhD, and \\ Yves d' Udekem, MD, PhD, Melbourne, Australia
}

\footnotetext{
From the Department of Cardiac Surgery, Royal Children's Hospital, the University of Melbourne Department of Paediatrics, and the Murdoch Children's Research Institute, Melbourne, Australia.

Disclosures: None.

Received for publication Sept 16, 2009; revisions received Nov 20, 2009; accepted for publication Dec 13, 2009; available ahead of print March 10, 2010.

Address for reprints: Yves d'Udekem, MD, PhD, Department of Cardiac Surgery, Royal Children's Hospital, Flemington Road, Parkville, Melbourne 3052, Victoria, Australia (E-mail: yves.dudekem@rch.org.au).

J Thorac Cardiovasc Surg 2010;139:1346-8 0022-5223/\$36.00

Crown Copyright $\Subset 2010$ Published by Elsevier Inc. on behalf of The American Association for Thoracic Surgery

doi:10.1016/j.jtcvs.2009.12.029
}

In recent years, dramatic early failure of the Fontan circulation has become exceedingly rare, ${ }^{1}$ although there are occasional deaths in patients with large ongoing chest drain losses. Fontan takedown to a prior palliative state has been described to allow successful survival of these patients, but only limited information exists on the early and longterm results of this rescue procedure. ${ }^{2}$

\section{CLINICAL SUMMARY}

Between January 1980 and December 2007, 413 patients underwent a Fontan procedure at the Royal Children's Hospital, Melbourne. During this period, 14 
TABLE 1. Patient characteristics

\begin{tabular}{|c|c|c|c|c|c|c|c|c|}
\hline $\begin{array}{c}\text { Diagnosis } \\
\text { (predominant } \\
\text { ventricular } \\
\text { morphology) } \\
\end{array}$ & $\begin{array}{c}\text { Age at } \\
\text { Fontan }(y)\end{array}$ & $\begin{array}{l}\text { Type of } \\
\text { Fontan } \\
\end{array}$ & $\begin{array}{l}\text { Timing of } \\
\text { takedown } \\
\text { (d) } \\
\end{array}$ & $\begin{array}{c}\text { Indication } \\
\text { for } \\
\text { takedown } \\
\end{array}$ & $\begin{array}{c}\text { Pulmonary } \\
\text { artery pressure } \\
\text { before takedown } \\
(\mathbf{m m ~ H g}) \\
\end{array}$ & $\begin{array}{c}\text { Ultimate } \\
\text { palliation }\end{array}$ & $\begin{array}{c}\text { Suspected } \\
\text { reason for } \\
\text { failure } \\
\end{array}$ & Final outcome \\
\hline AVSD (right) & 1.8 & $\begin{array}{l}\text { Lateral tunnel } \\
\quad \text { (fenestrated) }\end{array}$ & 0 & Low output & 11 & Bilateral BCPS & $\begin{array}{l}\text { Pulmonary } \\
\text { venous } \\
\text { obstruction }\end{array}$ & $\begin{array}{l}\text { NYHA class III } \\
\quad \text { with severe } \\
\text { atrioventricular } \\
\text { valve } \\
\text { regurgitation }\end{array}$ \\
\hline PA-IVS (left) & 3.4 & $\begin{array}{l}\text { Lateral tunnel } \\
\qquad(\text { fenestrated) }\end{array}$ & 0 & Low output & 20 & $\begin{array}{l}\text { BCPS with } \\
\text { left BT shunt }\end{array}$ & $\begin{array}{l}\text { Systemic- } \\
\text { pulmonary } \\
\text { collaterals }\end{array}$ & $\begin{array}{l}\text { NYHA class I after } \\
\text { successful re-do } \\
\text { Fontan at } 11 \mathrm{y}\end{array}$ \\
\hline DORV (right) & 19.7 & $\begin{array}{l}\text { Lateral tunnel } \\
\quad \text { (fenestrated) }\end{array}$ & 0 & Low output & 30 & BCPS & $\begin{array}{l}\text { Elevated } \\
\text { pulmonary } \\
\text { vascular } \\
\text { resistance }\end{array}$ & NYHA class I \\
\hline TA (left) & 4.4 & $\begin{array}{c}\text { Extracardiac } \\
\text { conduit }\end{array}$ & 0 & Low output & Unknown & BCPS & thrombosis & $\begin{array}{l}\text { NYHA class I after } \\
\text { successful re-do } \\
\text { Fontan at } 2 \text { y }\end{array}$ \\
\hline PA-IVS (left) & 3.4 & Atriopulmonary & 1 & Low output & 20 & Central shunt & $\begin{array}{l}\text { Elevated } \\
\text { pulmonary } \\
\text { vascular } \\
\text { resistance }\end{array}$ & Hospital mortality \\
\hline DILV-TGA (left) & 6.8 & Atriopulmonary & 2 & Low output & 17 & $\begin{array}{c}\text { Aortopulmonary } \\
\text { window }\end{array}$ & $\begin{array}{l}\text { Systolic } \\
\text { dysfunction }\end{array}$ & Hospital mortality \\
\hline $\begin{array}{r}\text { Primum ASD, left } \\
\text { isomerism (left) }\end{array}$ & 4.4 & Lateral tunnel & 2 & Low output & 25 & $\begin{array}{c}\text { BCPS } \\
\text { (Kawashima) }\end{array}$ & $\begin{array}{l}\text { Systolic } \\
\text { dysfunction }\end{array}$ & NYHA class I \\
\hline DILV-TGA (left) & 4.9 & $\begin{array}{l}\text { Lateral tunnel } \\
\quad \text { (fenestrated) }\end{array}$ & 13 & Low output & Unknown & BCPS & Thrombosis & $\begin{array}{l}\text { NYHA class III } \\
\text { after successful } \\
\text { BT shunt at } 5 \text { y }\end{array}$ \\
\hline HLHS (right) & 6.0 & $\begin{array}{l}\text { Extracardiac } \\
\text { conduit } \\
\text { (fenestrated) }\end{array}$ & 67 & Effusion & Unknown & BCPS & $\begin{array}{l}\text { Diastolic } \\
\text { dysfunction }\end{array}$ & Hospital mortality \\
\hline TA (left) & 5.0 & $\begin{array}{l}\text { Extracardiac } \\
\text { conduit } \\
\text { (fenestrated) }\end{array}$ & 73 & Effusion & 17 & $\begin{array}{r}\text { Bilateral } \\
\text { BCPS }\end{array}$ & Chylothorax & Hospital mortality \\
\hline HLHS (right) & 3.1 & $\begin{array}{c}\text { Extracardiac } \\
\text { conduit }\end{array}$ & 93 & Effusion & 16 & BCPS & $\begin{array}{l}\text { Pulmonary } \\
\text { venous } \\
\text { obstruction }\end{array}$ & NYHA class II \\
\hline HLHS (right) & 15.1 & $\begin{array}{l}\text { Extracardiac } \\
\text { conduit } \\
\quad \text { (fenestrated) }\end{array}$ & 163 & Effusion & 24 & BCPS & $\begin{array}{l}\text { Systemic- } \\
\text { pulmonary } \\
\text { collaterals }\end{array}$ & $\begin{array}{l}\text { NYHA class II } \\
\text { after successful } \\
\text { coil embolization } \\
\text { of collaterals }\end{array}$ \\
\hline DORV (right) & 4.0 & Atriopulmonary & 406 & Effusion & Unknown & $\begin{array}{r}\text { Aorta to left } \\
\text { PA shunt }\end{array}$ & Chylothorax & Hospital mortality \\
\hline AVSD (right) & 6.3 & $\begin{array}{c}\text { Extracardiac } \\
\text { conduit }\end{array}$ & 458 & $\begin{array}{r}\text { Protein-losing } \\
\text { enteropathy }\end{array}$ & 18 & $\begin{array}{l}\text { BCPS with } \\
\text { aorta to left } \\
\text { PA shunt }\end{array}$ & $\begin{array}{l}\text { Elevated central } \\
\text { venous } \\
\text { pressure }\end{array}$ & NYHA class I \\
\hline
\end{tabular}

NYHA, New York Heart Association; PA-IVS, pulmonary atresia with intact ventricular septum; DORV, double-outlet right ventricle; $D I L V$-TGA, double-inlet left ventricle with transposition of the great arteries; $A V S D$, atrioventricular septal defect; $H L H S$, hypoplastic left heart syndrome; $A S D$, atrial septal defect; $T A$, tricuspid atresia; $B C P S$, bidirectional cavopulmonary shunt; $B T$, Blalock-Taussig; $P A$, pulmonary artery.

patients $(3 \%)$ had their Fontan taken down to an intermediate palliative circulation $(3 / 152$ atriopulmonary connections, 6/105 lateral tunnels, and 5/156 of extracardiac conduits). The characteristics of these patients are pre- sented in Table 1. The comparative characteristics of the overall cohort of patients who underwent a Fontan and patients who had their Fontan taken down are presented in Table 2. 
TABLE 2. Comparative characteristics

\begin{tabular}{|c|c|c|c|}
\hline & $\begin{array}{c}\text { All Fontans } \\
\text { (413 patients) }\end{array}$ & $\begin{array}{c}\text { Takedown } \\
\text { (14 patients) }\end{array}$ & $\begin{array}{c}P \\
\text { value }\end{array}$ \\
\hline $\begin{array}{c}\text { Age at Fontan }(y), \\
\text { mean }(S D)\end{array}$ & $6.2(5.4)$ & $6.3(5.0)$ & .92 \\
\hline Male:female $(\%)$ & $57.8 \%$ & $64.3 \%$ & .63 \\
\hline $\begin{array}{l}\text { Pre-Fontan PA pressure } \\
\quad(\mathrm{mm} \mathrm{Hg}), \text { mean }(\mathrm{SD})\end{array}$ & $12.1(3.3)$ & $13.8(3.0)$ & .02 \\
\hline $\begin{array}{l}\text { Prior staging } \\
\quad \text { with BCPS, \% }\end{array}$ & $47.2 \%$ & $57.1 \%$ & .59 \\
\hline $\begin{array}{l}\text { Moderate or greater } \\
\text { atrioventricular valve } \\
\text { regurgitation, } \%\end{array}$ & $19.9 \%$ & $35.7 \%$ & .17 \\
\hline $\begin{array}{r}\text { Right ventricular } \\
\text { dominance, } \% \\
\end{array}$ & $50 \%$ & $31.2 \%$ & .15 \\
\hline
\end{tabular}
shunt.

\section{RESULTS}

In the initial period before 1990, 3 patients had their Fontan taken down to a systemic-pulmonary shunt. The remaining 11 patients had their Fontan taken down to a bidirectional cavopulmonary shunt (BCPS). Eight of the 14 patients $(57 \%)$ had their Fontan circuit fenestrated. Before takedown, 1 patient with a lateral tunnel had a conversion to an extracardiac conduit, 1 patient underwent attempted creation of a 4-mm fenestration, 1 patient was supported on extracorporeal membrane oxygenation, and the remaining 2 patients underwent pleurodeses.

\section{Hospital Mortality}

There were 5 hospital deaths for an overall hospital mortality of $36 \%$. All 3 patients with a takedown to a systemic-pulmonary shunt in the earlier era died within the first 2 postoperative days. Only 2 of the 11 patients $(18 \%)$ with a takedown to a BCPS died. Takedown was performed in both patients because of persistent effusions, which persisted after the Fontan takedown. Hospital mortality was $60 \%$ (3/5 patients) when takedown was indicated for prolonged effusions, $25 \%$ (2/8 patients) for low-output syndrome, and $0 \%$ for pleural effusion (1 patient).

\section{Follow-up}

Complete follow-up was available in all 9 hospital survivors at a median duration of 9 years ( $2-11$ years). There were no late deaths or cardiac transplantations. Two patients underwent an extracardiac fenestrated Fontan procedure 2 and 11 years after the takedown procedure, once reversible causes of failure were identified and treated. The first patient had thrombosis of his conduit and required pulmonary artery thrombectomy and reconstruction at the time of takedown. In the second patient, failure was attributed to the presence of systemic-pulmonary collaterals, which were embolized percutaneously. Both patients were in New York Heart Association class I at last follow-up. The remaining 7 patients were left with a BCPS palliation and were in New York Heart Association class I (1), II (4), or III (2).

\section{DISCUSSION}

There are scant data on outcomes after Fontan takedown, and the indications for this rescue procedure remain obscure. The Boston team have reported their experience with 52 patients undergoing operations over a 27 -year period. Their mortality decreased after 1990, a date that coincides with the introduction of fenestration and staging with BCPS. In our experience in the recent era, since we have started converting to a BCPS rather than a systemic-pulmonary shunt, we have not lost any patient undergoing operation for early hemodynamic instability. Only 2 of 5 patients who underwent operation for intractable effusions did not survive to discharge.

\section{CONCLUSIONS}

The number of patients presented in this article and by the Boston group remains small, making definitive conclusions difficult. One is left to subjective feelings to make decisions. Better indications for Fontan surgery have made takedown in this era rare, but prolonged effusions remain a recurrent issue. Early Fontan takedown for patients in low cardiac output is clearly an effective rescue measure. Fontan takedown performed later for prolonged large chest drain losses carries a higher mortality because it is usually performed when a patient's condition has considerably deteriorated; therefore, the ideal timing of takedown in this indication remains unclear. Because the mortality of those undergoing takedown is acceptable for this extreme situation and because surviving patients may expect durable survival, we suspect that takedown should be offered earlier rather than later. Late outcomes improved after reversible lesions were treated, and this report highlights once more that residual lesions should be aggressively sought. To prevent failure, we have already adopted a policy of systematic fenestration at the time of Fontan. ${ }^{3}$ Once the patency of the fenestration has been demonstrated, we believe that Fontan takedown should be offered for patients with prolonged effusions within 6 weeks, before their nutritional status deteriorates to the point where operative survival is impossible.

\section{References}

1. d'Udekem Y, Iyengar AJ, Cochrane AD, Grigg LE, Ramsay JM, Wheaton GR, et al. The Fontan procedure: contemporary techniques have improved long-term outcomes. Circulation. 2007;116(11 Suppl):I157-64.

2. Almond CS, Mayer JE Jr, Thiagarajan RR, Blume ED, del Nido PJ, McElhinney DB. Outcome after Fontan failure and takedown to an intermediate palliative circulation. Ann Thorac Surg. 2007;84:880-7.

3. Ruiz E, Guerrero R, d'Udekem Y, Brizard C. A technique of fenestration for extracardiac Fontan with long-term patency. Eur J Cardiothorac Surg. 2009;36:200-2. 